IZA DP No. 4651

Was there a Skills Shortage in Australia?

P.N. (Raja) Junankar

December 2009 


\title{
Was there a Skills Shortage in Australia?
}

\author{
P.N. (Raja) Junankar \\ University of Western Sydney \\ and IZA
}

\section{Discussion Paper No. 4651 \\ December 2009}

\author{
IZA \\ P.O. Box 7240 \\ 53072 Bonn \\ Germany \\ Phone: +49-228-3894-0 \\ Fax: +49-228-3894-180 \\ E-mail: iza@iza.org
}

Any opinions expressed here are those of the author(s) and not those of IZA. Research published in this series may include views on policy, but the institute itself takes no institutional policy positions.

The Institute for the Study of Labor (IZA) in Bonn is a local and virtual international research center and a place of communication between science, politics and business. IZA is an independent nonprofit organization supported by Deutsche Post Foundation. The center is associated with the University of Bonn and offers a stimulating research environment through its international network, workshops and conferences, data service, project support, research visits and doctoral program. IZA engages in (i) original and internationally competitive research in all fields of labor economics, (ii) development of policy concepts, and (iii) dissemination of research results and concepts to the interested public.

IZA Discussion Papers often represent preliminary work and are circulated to encourage discussion. Citation of such a paper should account for its provisional character. A revised version may be available directly from the author. 
IZA Discussion Paper No. 4651

December 2009

\section{ABSTRACT}

\section{Was there a Skills Shortage in Australia?}

The paper analyses the problem of a "skills shortage" in Australia. It begins with an analysis of the operation of a labour market in terms of stocks and flows of labour services and human capital acquisition. It discusses the definition of a skills shortage, why it persists, and then looks at evidence from Australia, in particular, the resource rich states of Queensland and Western Australia over the past decade. It discusses possible employer responses to a skills shortage. Finally, it discusses whether the government should intervene, and if so what policies may help to relieve a skills shortage.

JEL Classification: J24, J31, J48

Keywords: skill shortages, wage adjustments, migrants

Corresponding author:

P.N. (Raja) Junankar

School of Economics and Finance

College of Law and Business

Campbelltown Campus

University of Western Sydney

Locked Bag 1797

Penrith South DC, NSW 1797

Australia

E-mail: raja.junankar@uws.edu.au 


\section{Introduction}

Over the past decade, until the onset of the Global Financial Crisis, there was much talk of a skills shortage in Australia. The employers' organisations were talking about the difficulties of finding skilled workers and were demanding that the government should increase the quotas for skilled migrants, and to expand the temporary 457 visas. The rapid growth of the Australian economy had led to lowest unemployment rate in about 30 years and vacancy rates had been increasing. The resource rich states, Western Australia and Queensland were growing very rapidly and were attracting labour from the other states. There was anecdotal evidence of commuter flights leaving Sydney on Monday mornings and returning on Friday evenings and temporary housing was being organised in containers to house the temporary migrants. Suddenly, the world has changed: commodity prices have collapsed, the Chinese economy has slowed down, and we are now facing a prolonged recession with increasing unemployment. What policies should the government introduce to help employers if there is a skills shortage? Now that the labour market has collapsed, should the government cut back on skilled migration? Can we use changes in migration quotas to stabilise the business cycle?

The aim of this paper is to discuss the concept of a skills shortage and the responses of workers and employers to such a shortage. Although we will study Australia as a whole, we will concentrate on the resource rich states of Western Australia and Queensland. Section 2 provides some information about the developments in the Australian labour market; Section 3 discusses some issues in analysing the labour market; Section 4 discusses the concept of a skills shortage; Section 5 discusses how employers, workers, and the labour market respond to skill shortages; Section 6 studies the conditions in Western Australia and Queensland; and Section 7 concludes by looking at some government policies to resolve skills shortages.

Standard neoclassical economics predicts that if there is a skills shortage, the labour market would respond with large increases in wage rates. Our results, however, show that real wages were growing at a relatively slow rate (compared to productivity growth) and even in Western Australia and Queensland the wage rates of skilled occupations were growing very slowly. 


\section{The Labour Market: Some Stylised Facts}

As the Australian economy had grown rapidly over the past decade or more, employment had grown rapidly, unemployment and long term unemployment were at 30 year lows (Figures 1 and 2): unemployment had fallen to $4.1 \%$ in January 2009. Since the Global Financial Crisis hit, unemployment has started increasing and almost all forecasts now suggest that it will continue to increase over the next year or two. Job vacancies had been growing and the ratio of vacancies to unemployed workers had been growing consistently over the past few years, Figure 3. Real wages had been growing relatively slowly (at 1.4 $\%$ per annum since the last recession of the early 1990s, while labour productivity had grown at $2.3 \%$ per annum) and Real Unit Labour Costs in the non-farm sector had been falling more or less consistently since the 1990s, Figure 4. That real unit labour costs were falling implies that the share of profits in GDP was rising over the same period. Hence, workers were not doing as well as the capitalists even though labour was in high demand and there were apparently skilled labour shortages. Real average weekly ordinary time earnings had been growing at an average of $1.67 \%$ per annum over the period September 1993 to December 2007 (Figure 5) while the average rate of growth of GDP was $3.7 \%$ per annum. Hence even in a period of rapid growth and increasing demand for labour real earnings were not growing as rapidly as the economy.

\section{Figure 1: Unemployment Rate}

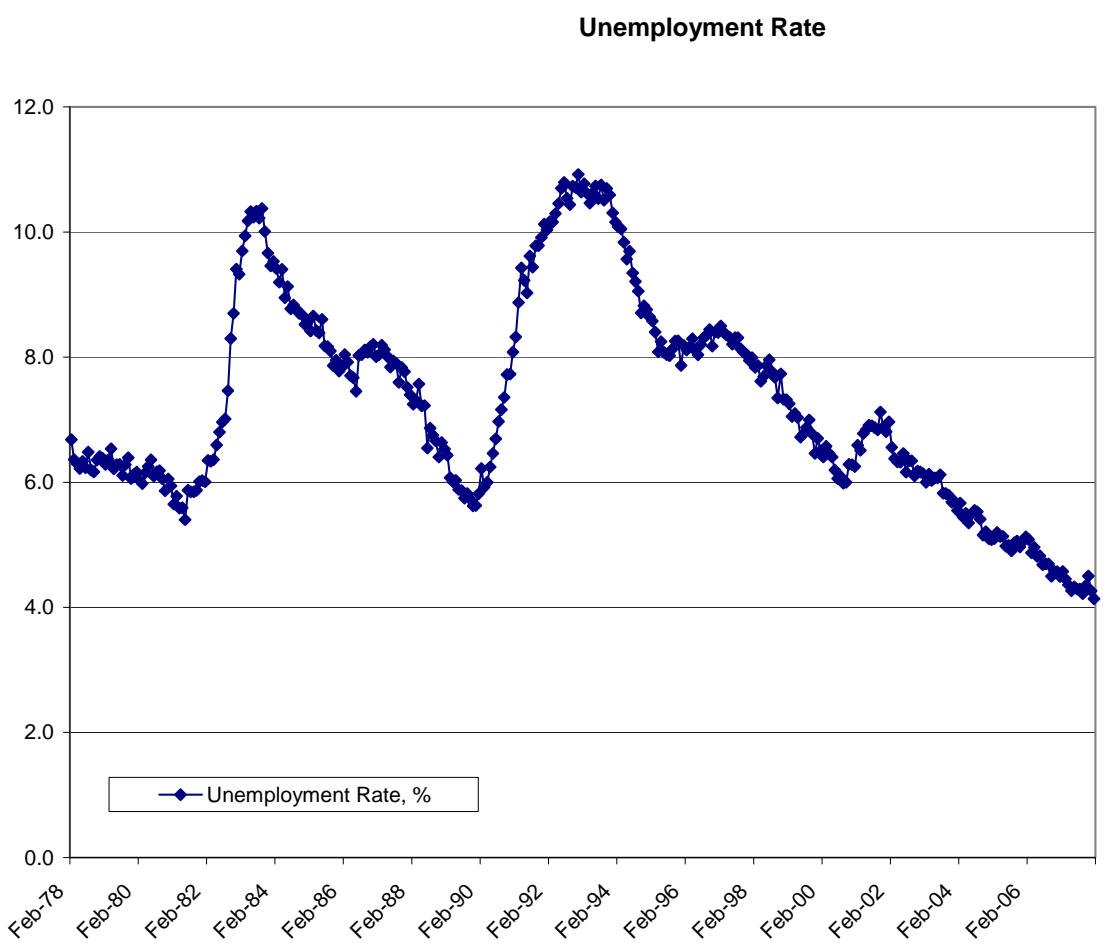

Source: RBA 
Figure 2: Long Term Unemployment as a percentage of Total Unemployment Long Term Unemployment, Persons (sa)

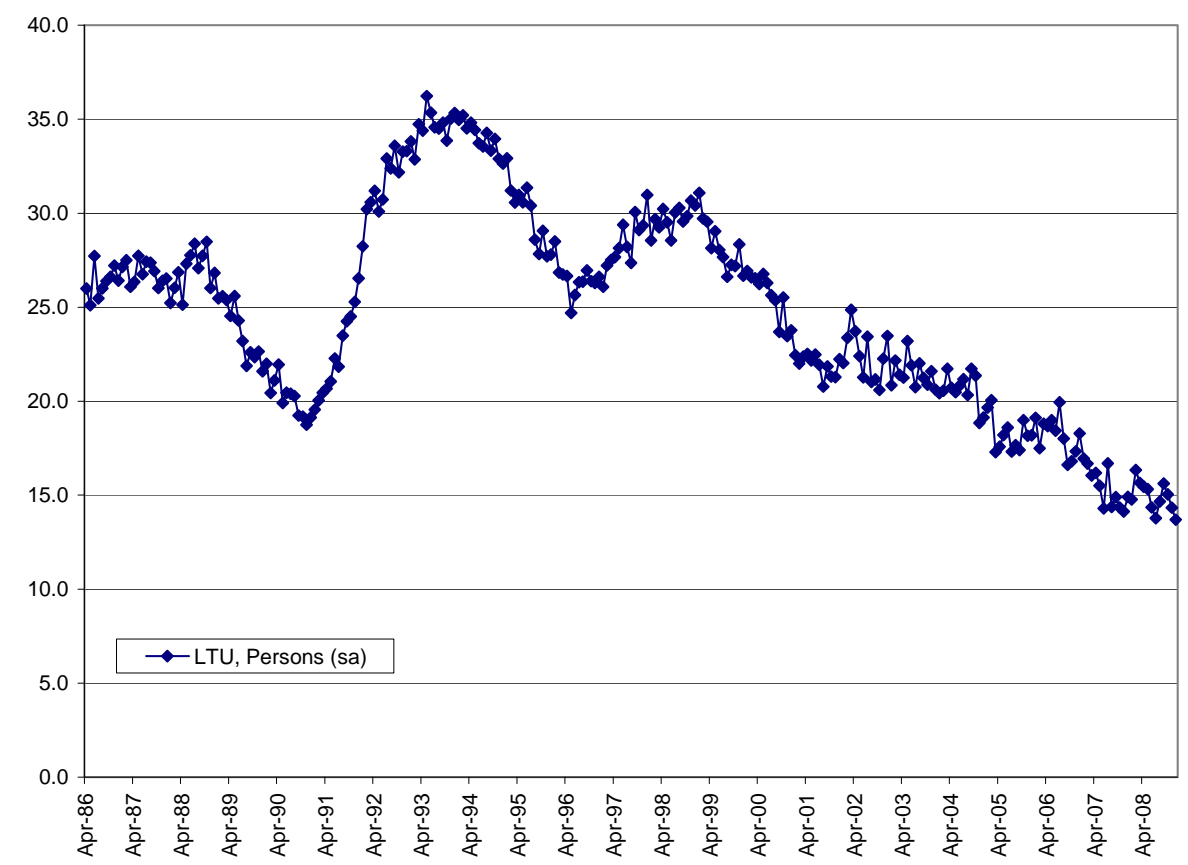

Source: ABS

Figure 3: Vacancy-Unemployment Ratio (\%)

Vacancies per Unemployed Person

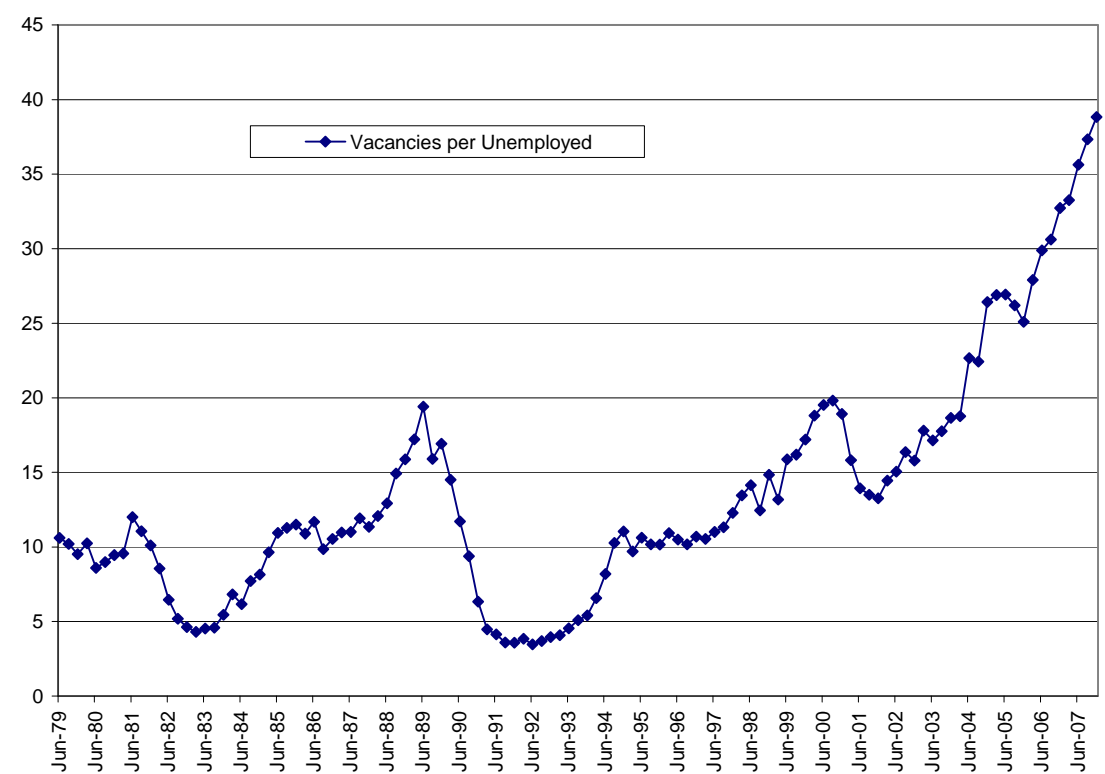

Source: RBA 
Figure 4: Real Unit Labour Costs (Non-Farm Sector)

Real Unit Labour Costs, Non-Farm

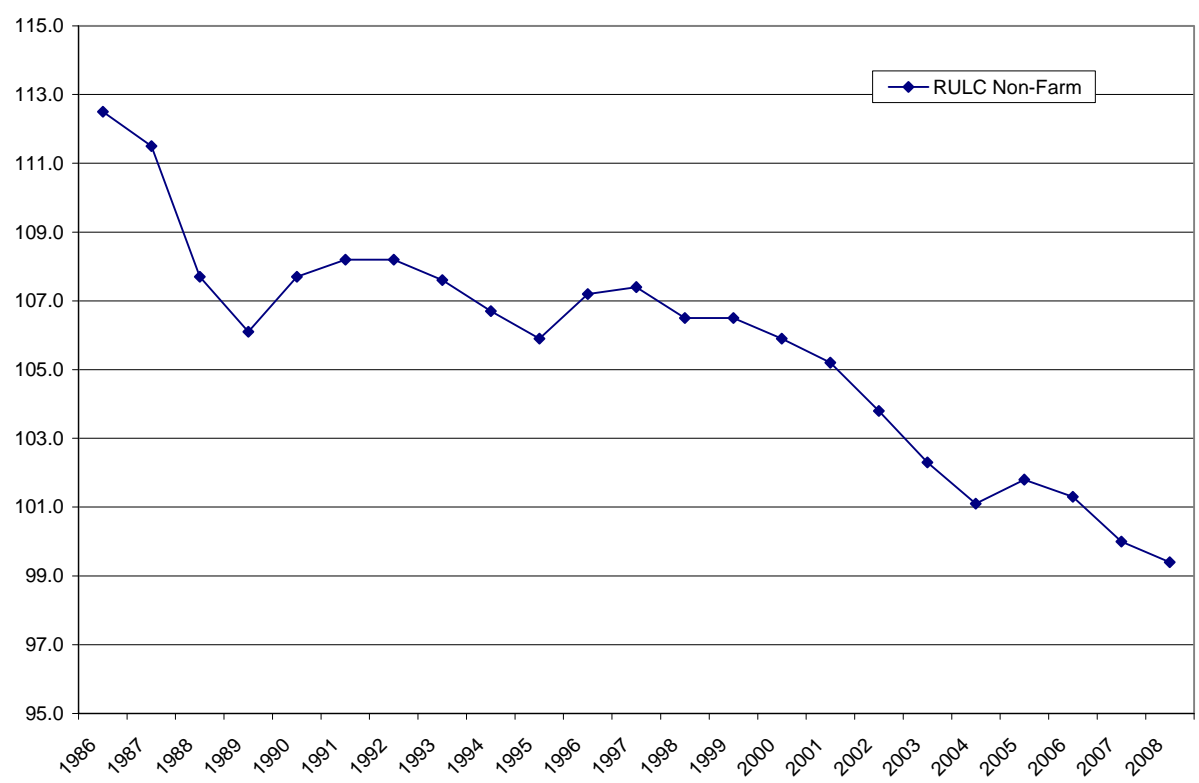

Source: ABS

Figure 5: Growth of Real Average Weekly Ordinary Time Earnings

Growth Rate of RAWOTE

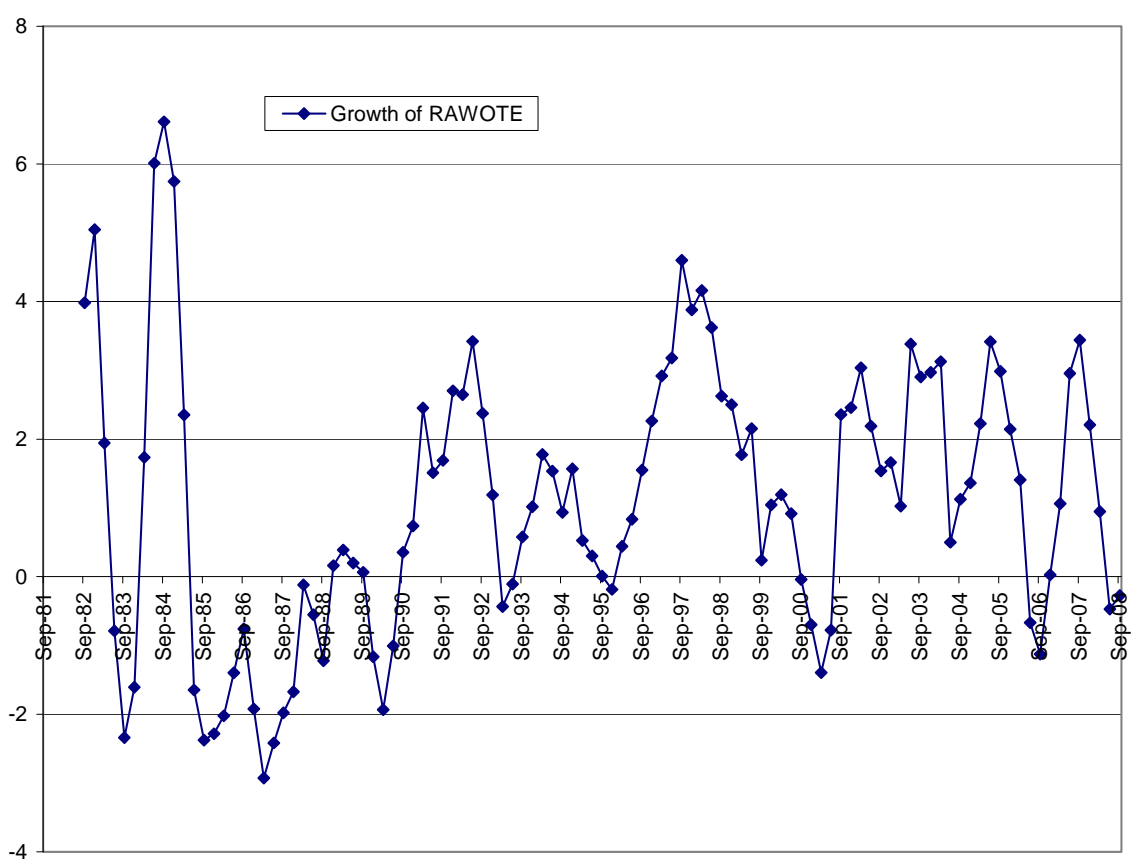

Source: RBA 


\section{Some problems in Analysing a Labour Market}

Although some economists may treat the labour market as if it were like a market for any other good/commodity, the labour market has distinct characteristics that make it difficult to analyse. An important reason for the labour market being distinctive is that the commodity being exchanged is the services of labour which depends not only on the number of persons working but the efficiency and timeliness of the services.

The labour market does not operate as an auction market where adjustment is instantaneous. Firstly, it is a social institution and is therefore bound by rules of social behaviour. Unlike the market for (say) fresh tomatoes, if there is an excess of labour on the market we cannot just dispose of the excess in the garbage bin! There are a range of institutional constraints that operate: custom and practice are important. There is a spectrum of qualities of labour supplied and demanded. There are different labour markets: geographic, industry, occupation, skills, etc. Labour mobility across occupations and across geographical areas is imperfect. Since labour is heterogeneous, the matching of the demand for labour with the supply of labour is difficult and time consuming. Further, in negotiations regarding wage rates there are institutional constraints: minimum wages, union pressures, and ideas of fairness. In a labour market, information is asymmetric: if a worker offers his/her labour services the employer does not really know the quality of these services prior to employing that person.

In a labour market the quantity and quality of labour services that an employer obtains from her employees depends on the motivation of the employees: if they feel they are being treated well they would reciprocate and provide better quality labour services. Since most employment contracts are fairly long term, good conditions of work can decrease turnover of skilled staff. The conditions of work that may influence the quality of labour services include the physical conditions, but also the way the managers treat the workers. Similarly, attracting (and retaining) skilled workers requires not only offering "competitive" wages, but also flexibility of work place conditions, child care facilities, etc. Again, an employer who wishes to do well needs to provide workers with good promotion prospects to encourage continuity of employment of skilled workers and lead to increased productivity.

An important aspect of the supply of labour is the amount of human capital embodied in the worker. Unlike the purchase of physical capital, human capital is an irreversible investment: the human capital cannot be separated from the worker. Time is a critical element in the building of human capital. Hence there are long lags between an increase in the demand for skills being met by increased supply from the home country.

Acquisition of human capital may be by formal methods, like degrees in universities, diplomas in TAFEs, by apprenticeships, or it can be informal, like training in the workplace. Formal education may provide specific or vocational degrees or general degrees that may be more flexible in a changing environment, but they involve a long period of education. There is much human capital formation that takes place on the job, what economists call "learning by doing": hence continuity of employment is important. 
A much neglected issue in training workers is that it provides an externality to the rest of the labour force.

Apprenticeships are critical in many trades. At one time the public sector provided much training to the young via apprenticeships, but with the privatisation programs of the 1980 and 1990s, and the corporatisation of the public sector agencies, these apprenticeships have almost disappeared.

\section{What is a Skills Shortage?}

Although there is much talk of a skills shortage there has been little economic analysis carried out to explain the determinants of a shortage and the implications of a shortage on the functioning of the labour market. Economists define a skill shortage as one where the demand for a particular kind of labour exceeds the available supply at the current wage. Although an easy concept to define, it is very difficult to measure. Even the OECD (2003) says that "There is no universally applied definition of labour shortages."

Let us assume that there is an initial equilibrium in the labour market for a particular type of skilled labour, e.g. skilled miners. In other words, the demand for skilled miners is exactly equal to the supply of skilled miners in (say) Western Australia. Then as a result of the growth of the Chinese economy there is a mining boom and the mining corporations would like to expand their production to meet the increased demand for (say) coal. In the immediate short run the firms would like to hire more skilled miners but they cannot hire any more as they are not available: there is an excess demand for this skill at the existing wage rate. In traditional economics, this excess demand should lead to an increase in the wages of these skilled miners as firms try to attract more workers. See diagram below.

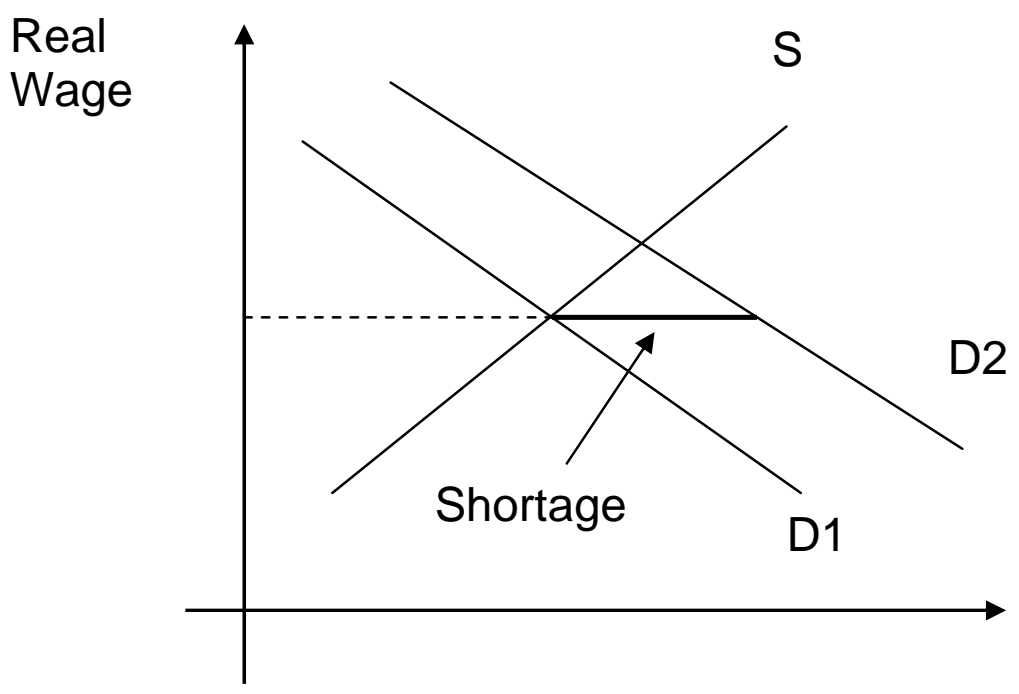

Units of labour services 
However, as the labour market is not an auction market, the wage rate may not adjust instantaneously and the excess demand would persist. In any case, even if wages were to adjust immediately, the number of skilled workers cannot expand immediately (unless they were to move from another location costlessly and instantaneously). For the supply of this type of skilled labour to increase, either some unemployed workers would have to be trained in this skill, or workers who have other skills would have to retrain. However, people do not acquire new skills unless they believe that the current shortage will last for a long time so that when they have acquired the new skills they will still be in demand. Expectations about the skills shortage have to be persistent for workers to invest in new skills.

There has been much discussion about the difficulties involved in defining and measuring a skill shortage. Arrow and Capron (1959) define a shortage as "a situation in which there are unfilled vacancies in positions where salaries are the same as those currently being paid to others of the same type and quality.” (p. 307) Even the concept of a vacancy is difficult to measure. Some data on vacancies may be out of date, some firms may simply have a "standing order" of vacancies to allow for natural wastage, and vacancies are often duplicated on different lists. '... vacancies are frequently duplicated and dated. At any point in time, around $14 \%$ of vacancies are duplicated. Over time, the duplication rate is substantially higher, at over 46\% ...' (Auditor General 2006, p.17).

For example, the Department of Employment and Workplace Relations quoted in Department of Education, Science and Training 2000, p. 4 provide an attempt to define what a skill shortage is:

"Skill shortages exist when employers are unable to fill or have considerable difficulty in filling vacancies for an occupation, or specialised skill needs within that occupation, at current levels of remuneration and conditions of employment, and reasonably accessible location.

Skill gaps occur where existing employees do not have the required qualifications, experience and/or specialised skills to meet the firm's skill needs for an occupation. Workers may not be adequately trained or qualified to perform tasks, or may not have upskilled to emerging skill requirements.

Recruitment difficulties may be due to characteristics of the industry, occupation or employer, such as: relatively low remuneration, poor working conditions, poor image of the industry, unsatisfactory working hours, location hard to commute to, inadequate recruitment or firmspecific and highly-specialised skill needs.”

However, a high level of vacancies in a particular occupation in a particular region may simply reflect that there is a high turnover of staff in that place. The duration of an unfilled vacancy may provide some information about a skills shortage, however, data are not available on this basis. Some indicators of a skill shortage would be the length of time 
taken to fill vacancies; low unemployment of workers with particular skills, persistent use of overtime, increasing wages, high turnover of skilled staff, "poaching”, lowering of hiring standards, etc. Again, data on these variables are not easily available. It is worth noting that one employer may fill a skills shortage by poaching, but that does not solve the skills shortage in general!

Employers often find it difficult to fill a vacancy because they not only require some technical skills, but also social skills, communication skills, motivation, etc. The conditions of work are often difficult or in poor locations and hence employers find difficulty in filling vacancies. If the position is temporary, it is unlike to lead to workers moving from one geographic location to another. However, if the wages are sufficiently high we may find workers are willing to move geographically. During the rapid growth of mining in Western Australia many workers were commuting on planes from Sydney to Perth on Mondays and Fridays!

\section{How does the market respond to skill shortages?}

Given that there are skilled labour shortages, how does the market respond? The employers could respond by changing wages or other conditions, the suppliers of labour could respond by acquiring the necessary skills by investing in human capital, or the government could respond increasing training opportunities, increasing apprenticeships, or by changing the conditions for allowing skilled migrants into the country.

Given that there are labour shortages, how do employers respond? Economic theory clearly predicts that if there is excess demand for a particular skill, wages would be driven up, either by the employers trying to persuade workers to work for them, or by workers demanding higher wages. However, if employers pay higher wages for new employees they would be forced to pay higher wages to existing workers as well. Note that there are no legal restrictions on employers increasing wages to meet the excess demand ${ }^{1}$. If they did raise wages, the excess demand would disappear. The question that remains is, "why do employers not raise wages in times of skilled labour shortages?" We will turn to this issue when we consider the evidence from Western Australia and Queensland.

If employers do not respond by raising wages, in the short run they could try to use the existing labour force more intensively, that is increase over time work. A longer run response is to decrease the turnover of staff by offering better working conditions, e.g. better career prospects, provision of benefits in kind, e.g. more flexible working times, child care facilities, etc. A similar strategy would be to hold on to employees who are planning to retire and to retain the experienced older workers.

Another strategy for employers would be to train existing unskilled workers, or to hire more apprentices and train them up to fill the shortages. Alternatively, employers could increase recruitment in previously untried areas, e.g. recruit women workers, recruit from

\footnotetext{
${ }^{1}$ Unlike legal restrictions that employers are not supposed to pay less than the minimum wage, there are no legal restrictions on paying more than the minimum wage!
} 
other geographical locations (either within the state or outside the state), and of course recruit overseas. In recent days, many employers were using the (relatively) new temporary 457 visas to hire migrant workers.

An even longer term strategy is to change production methods by using more capital to replace labour. New technology, robotics in the workplace, has replaced labour in some firms. Finally, firms can always try to outsource particular activities to alleviate skilled labour shortages.

Another strategy to alleviate labour shortages may be to "lower hiring standards". This sounds radical, however, many employers use some characteristics of the potential employees that are not essential, e.g. employers in the past may have rejected a male applicant simply because he had long hair and did not look tidy. Another way of "lowering hiring standards" could be by employers providing their workers their own tools/safety clothes etc. where previously they expected their workers to bring their own equipment.

From the supply side, there can be an increase in skilled labour supply if unskilled workers (or workers with skills that are no longer in demand) invest in training in the fields that are now in high demand. However, some skills require a long period of training and potential workers may not wish to invest if they believe that the skills shortage is temporary. As we know, with the sudden collapse in the world economy there has been a fall in demand for labour in general, but also for skilled workers in mining, etc.

It is interesting to note that in many OECD countries, including Australia, there are many workers who are working in jobs/occupations where they are over-qualified:

- "It is found that approximately 15.8 per cent of men and 13.6 per cent of women are overeducated, whereas approximately 18.5 per cent of women and 13.7 per cent of men are undereducated". Voon \& Miller (2005)

Does this mean that our education and training system is failing in providing the appropriate forms of skills?

Government policies can help to overcome skilled shortages, however, they are fairly long run in nature. A government could increase the incentives to employers to hire more apprentices, or it could encourage school students to stay on in school or by expanding the expenditures on TAFEs. In a globalised world, the government can increase the number of skilled migrants that it allows into the country. In recent years, the government introduced a new form of visa for temporary skilled workers.

\section{Was there as Skills Shortage in Western Australia and Queensland?}

The States of Western Australia and Queensland had been growing very rapidly prior to the Global Financial Crisis. An index of the shortages of labour often used is the vacancy 
to unemployment ratio. Figure 6 below clearly shows that labour shortages were appearing from the early 1990s, but especially since 2001 in both states. Unfortunately, we have no data on the duration of vacancies that would provide additional information. We also do not have data on vacancy unemployment ratios for different skills, although the growth of mining in these states was clearly driving the shortages, see Figure 7 below. 
Figure 6: Vacancy Unemployment Ratios, Queensland and Western Australia Vacancy to Unemployment Ratio (\%)

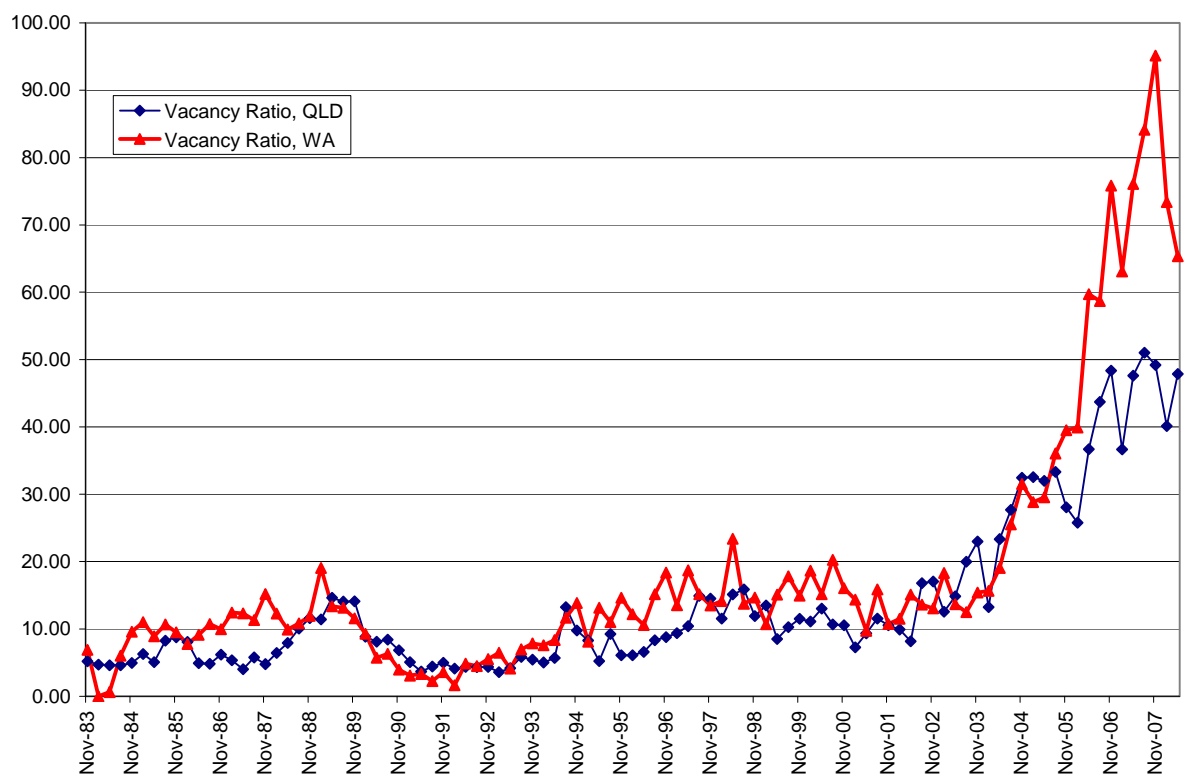

Figure 7: Vacancy Indexes by Industry, Mining and Manufacturing Job Vacancies by Industry (May 1996=100)

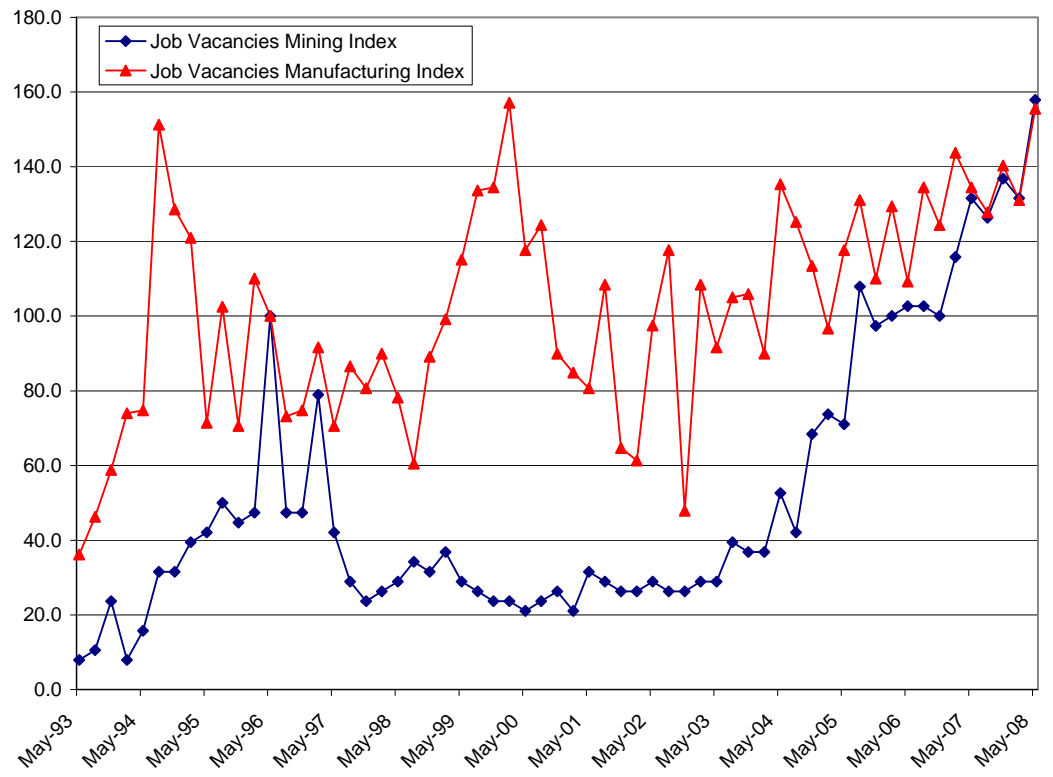


To study the extent to which there was a skills shortage in these States we will look at the behaviour of wages over the period 1996 to 2006 for which we have data from the ABS. We find that wage growth was higher in WA but lower in QLD compared to NSW or Australia. That suggests that Queensland did not have such a shortage of labour compared to NSW. Further, WA and QLD were growing rapidly ostensibly due to the rapid growth of mining in those states. However, wage growth of mining in WA or QLD was less than in manufacturing. We also find that wage growth in different occupations was not higher in QLD and WA compared to NSW or Australia.

Table 1: Annual Average Growth in Real Weekly Ordinary Time Earnings, 1996-2006 (Males)

\begin{tabular}{|l|l|l|r|r|r|r|r|}
\hline & $\begin{array}{l}\text { All } \\
\text { indus./all } \\
\text { occs. }\end{array}$ & $\begin{array}{l}\text { Miningl } \\
\text { All } \\
\text { Occs. }\end{array}$ & $\begin{array}{l}\text { Mfg.IAll } \\
\text { Occs. }\end{array}$ & Profs. & $\begin{array}{l}\text { Trades- } \\
\text { persons \& } \\
\text { Related } \\
\text { Workers }\end{array}$ & $\begin{array}{l}\text { Intermed. } \\
\text { Prod. \& } \\
\text { Transport }\end{array}$ & $\begin{array}{l}\text { Labs \& } \\
\text { Related } \\
\text { Workers }\end{array}$ \\
\hline Aus & 1.92 & 2.06 & 1.83 & 2.34 & 2.19 & 1.83 & 0.62 \\
\hline QLD & 1.71 & 1.24 & 1.87 & 1.81 & 1.89 & 0.74 & -4.35 \\
\hline WA & 2.56 & 1.75 & 2.21 & 2.57 & 2.22 & 1.59 & 0.41 \\
\hline NSW & 2.06 & 1.94 & 2.22 & 1.07 & -0.13 & 2.51 & na \\
\hline
\end{tabular}

Source: ABS Employee Earnings and Hours, ABS Cat No. 6306.0

If we look at the wage growth in mining in Western Australia (Table 2), we see that although managers and professionals were getting large annual average increases of 3.7 $\%$ and $2.57 \%$ (respectively), skilled workers (intermediate production and transport workers and Labourers and related workers) had much lower annual growth of earnings ( $1.59 \%$ and $0.41 \%$ respectively). If there was a real shortage of skilled labour we would expect that the annual wage growth in mining for these skilled groups would have been much higher than for other groups. However, it looks like managers and professionals were enjoying the benefits of the mining boom, while skilled workers were being left behind. 
Table 2: Mining in Western Australia, 1996-2006

\begin{tabular}{|l|r|r|}
\hline & $\begin{array}{l}\text { Average Annual Real Wage } \\
\text { Growth \% }\end{array}$ \\
\hline Managers & \multicolumn{2}{|c|}{3.7} \\
\hline Professionals & \multicolumn{2}{|c|}{} \\
\hline Assoc. Professionals & \multicolumn{2}{|c|}{} \\
\hline Tradespersons & na \\
\hline Adv. Clerical Services & na & 2.29 \\
\hline Inter.Clerical Sales services & & 1.59 \\
\hline Intermediate Production \& & & 0.41 \\
\hline Transport & & 1.75 \\
\hline Labourers and related workers & & \\
\hline All occupations & & \\
\hline
\end{tabular}

Source: ABS Employee Earnings and Hours, ABS Cat No. 6306.0

It is also interesting to read the advertisements for skilled workers in Job Search Australia (www.jobsearch.gov.au) where the following were listed in early 2008:

\section{Sample Advertisement 1}

- Here is an advertisement for Perth:

- Location:WA BELMONT

- Positions:2,New

We are looking for reliable, enthusiastic hard working container unloaders. To be successful for these positions you must be confident in lifting up to $25 \mathrm{~kg}$. Your main duties will include loading and unloading goods. Applicants must have steel capped boots, safety vest and own transportation is essential. **Please note these positions are casual. No phone applications please**

This position is Temporary, Casual ( hours: )

\section{Sample Advertisement 2}

\section{Location:WA REDCLIFFE}

Positions:2 New

We are looking for a Mechanical Fitter to assist with the repairing and fixing of an Austin Western Crane. This position is a temporary position and are looking for someone to start asap. Hours are from Mon-Fri 7am-3.30pm. Please call asap on

This position is Temporary, Full-Time

\section{Sample Advertisement 3}

Location: WA

WELSHPOOL

Emp Ref: $X X X$ 
Salary: Shift Rates+ Overtime, New

Our Client based in Welshpool is seeking experienced Forklift Drivers with a Can-Do-Attitude to join their team on a permanent fixed Day shiffternoon shift, Afternoon Shift or Night shift A competitive pay rate with opportunities to increase your dollars after completing a 3 month probationary period. Also good working conditions and a supportive working environment are offered. To apply for this position you must be fit \& able to carry out manual lifting on a daily basis as well as have: overhead crane ticket or exp is an essential requirement for the afternoon shift.

PreferredLicence(s):

Forklift Truck, Car.

This position is Permanent, Full-Time (hours: 38+Overtime)

\section{Sample Advertisement 4}

\section{Location:WA REDCLIFFE}

Emp Ref: XXX We require a safety aware, experienced boilermaker for a quality client on a remote mine site in the east Pilbara. Previous demonstrated experience on O\&K, Hitachi or Liebherr excavators will be highly regarded. This is a FIFO position only out of Perth or Brisbane direct, 12 hour shifts, 2 weeks on, 1 week off, coming in on night shift and shift change to day shift for the second week, and going out on days. The work can be very challenging, working in hot, dry, dusty conditions in the summer months when ambient air temperatures are high. If you are a team player that is happy to assist whenever and wherever required, the rewards are high. A good attitude towards a safe work environment is required at all times.

This position is Temporary, Casual (hours: Casual)

What is interesting is that even though employers were claiming that there were skill shortages they were advertising jobs that were temporary, casual, with peculiar shifts, difficult environments, requiring workers to bring their own equipment (capped boots), etc. Given that there was a skills shortage we would expect employers to provide better conditions of work, offer longer term contracts, and certainly provide essential equipment. Looking at these advertisements it does not look as if the employers had recognised that the labour market had changed at that time.

Thus both the evidence on real wages and a sample of advertisements for skilled workers suggests that in the face of a skills shortage, if it did exist, employers were not responding by increasing wages or "lowering standards". Perhaps they were busy persuading the government that there was a skills shortage so that they could hire migrants on temporary visas at lower real wages.

\section{Some Conclusions}

In this paper we have argued that there are conceptual problems in defining a skills shortage, there are significant problems in measuring a skill shortage, and that although there were significant increases in the demand for labour and a shortage of vacancies the labour market did not respond (even in the resource rich states of Queensland and Western Australia) by increasing real wages. We suggested that firms that were facing skills shortages could respond by raising wages, making conditions of work more favourable for new employees, lowering turnover, and generally treating their workforce 
with more generosity. We argued that due to the long lags involved, it would be difficult to get workers to train in new areas unless they felt that the increased demand for particular skills was a long term increase. They would need to be provided with appropriate incentives to increase their training by, for example, subsidising their training. We discussed briefly policies that a government should introduce to alleviate a skills shortage in terms of increased support for apprenticeships, increases in training for younger people at TAFES, and possibly increases in temporary migration visas.

Should government policy rely on temporary migration for skilled migrants? Firstly, forecasting skills shortages is difficult and hence the migration categories that are given priority tend to be those that were in high demand sometime in the past and hence may need to be revised constantly. Such short term adjustment to skills shortages is difficult: even if we expanded the numbers allowed in a particular visa category today, by the time employers have managed to find suitable employees a long time may have elapsed. Secondly, as the sudden collapse of the OECD economies has shown it is difficult to forecast accurately the overall growth of GDP, let alone the growth of demand by industry or occupation. Eventually, a government must rely on appropriate education and training opportunities for its own citizens, rather than relying on hiring migrants to fill skill gaps. Migration policy has to be based on long term goals, rather than be used as short term stabilisation measure.

As the Global Financial Crisis has hit most of the OECD countries and begins to hit the Australian economy, we are likely to see the growth of unemployment and long term unemployment. This would most likely affect the young, the unskilled, the poorly educated, and migrants (especially the non-English speaking migrants). This is a time for the government to increase its expenditures on training, apprenticeships, and subsidised courses in TAFEs. That would help the economy to be prepared to expand when the world economy (especially China) begins to expand again. 


\section{References}

- Department of Employment and Workplace Relations website, www.jobsearch.gov.au/joboutlook/.

- Green, F, Machin, S \& Wilkinson, D (1998), 'The meaning and determinants of skills shortages', Oxford Bulletin of Economics and Statistics, vol.60, no.2.

- Migration Advisory Committee (2008) Skilled Shortage Sensible, Home Office, London, UK.

- OECD (2003), Employment outlook, OECD, Paris.

- Richardson, Sue (2007) What is a Skills Shortage, National Centre for Vocational Education Research (NCVER), Adelaide.

- Shah, C \& Burke, G (2005), 'Skills shortages: Concepts, measurement and implications, Australian Bulletin of Labour, vol.31, no.1.

- Voon, D. and P.W. Miller (2005) "Undereducation and Overeducation in the Australian Labour Market”, Economic Record, 81 (255), S22-S33. 